\title{
GIFTED PUPILS IN THE CROATIAN AND SLOVENIAN EDUCATIONAL SYSTEM
}

\author{
mr.Mirela Bedeniković Lež \\ OŠ "Klinča Sela" \\ mrmirella@gmail.com
}

\begin{abstract}
Development and progress of every society depend heavily on the relationship with its most capable members and on the adequate care for the development of their potential. Gifted students are certainly one of the most important components of the society, and should be specialy taken care by the educational system. Unlike the Republic of Croatia, where the development of this group of pupils, in the educational system, has been neglected, most European countries are more and more aware of the importance of the curriculum, based on an individualized approach to gifted students and the formation of national strategies and educational policies for working with gifted. The Republic of Slovenia has been implementing its successful model of work with gifted students for fifteen years. Several concepts have been developed to reveal gifted students on the basis of which curriculum is being developed, moreover, the right and position of gifted students are legally defined through a multitude of documents. Likewise, great attention is devoted to the professional training and improvement of teachers for working with gifted students. Looking at the positive examples of neighboring countries in working with gifted students, it is essential to work on improving relations with gifted students and systematic care in schools in the Republic of Croatia.
\end{abstract}

Keywords: differentiation, educational system, giftedness, identification 


\section{INTRODUCTION}

In everyday life, the concept of giftedness is often encountered. Usually, it is interpreted as a set of inherent traits and abilities that allows the person possessing them, to consistently achieve above-average results in one or more different areas (CvetkovićLay, Sekulić-Majurec, 2008). If giftedness is expressed only in one area of activity, this phenomenon is also called talent (e.g. mathematical, artistic, musical, etc.). Giftedness is commonly associated with the term of above-average intelligence and creativity. Opinions on the frequency of giftedness in the total population are very different: from the ones who think there are only a few percent gifted to those who think most people are gifted for some area of activity.

Gifted children have above-average intellectual abilities, exceptionally good memory, learn fast and easy, are curious about research by themselves, are creative and have specific personality traits. They begin to develop and master some specific areas much faster than average children, mostly because they are learning and mastering skills in these areas faster and easier. They read a lot, use rich vocabulary, have a wide range of interests and are open to new, extracurricular knowledges. They do not fit into the usual expectations, neither by behavior nor by success at school. Very often gifted children remain unnoticed and ranked among the average pupils because their environment does not pay them the necessary attention.

Therefore, the hot topic is always how to develop giftedness in school, how to improve the educational process and enable the learner to fully develop his potential and not to fit into the pupil population of the average skills and to neglect his talent. That is why, besides high skills, importance lay on motivation for learning and developing specific interests that gifted children show early, goal orientation, work energy that helps them achieve their goals and rich, creative, and stimulating environment. School environment should provide maximum of such support in developing.

\section{Giftedness, ability, creativity - the meaning of concepts}

The concept of giftedness can be defined in many ways. Currently around 150 definitions are used in the scientific world. Landau (1990, according to Cvetković Lay, 2010) defines giftedness as "a delicate and accidental combination of emotional and cognitive and factors of environment, moreover, finding a delicate balance of these factors is challenging to anyone who works with gifted children". Grgin (1996) states that gifted pupils are those who stand out either by their very high level of general intellectual development or by the express development of only certain abilities that make them more advanced than other pupils. Marland (1971) points out that gifted children are those who, due to their exceptional abilities, can expect high achievements and are identified by experts. They show potential in one of the following areas: general intellectual ability, specific academic abilities, creative abilities, leadership and management skills, artistic ability and psychomotor skills. Such sample of children encompasses $3-5 \%$ of the school 
population.

Ability is a set of inherited and acquired conditions that enable the exercise of some activity, i.e. condition some form of behavior (JLZ, 1955-1964, 7: 129). Abilities are distributed in the population by the Gaussian curve. This means that the most of the population are average individuals, while the number of those who have an ability developed more or less than the average symmetrically decreases on both sides of the curve. Those individuals who have significantly above the average developed one or several abilities are considered gifted in one or many abilities (Koren, 1989).

Under the term creative person, we consider an individual who, besides a very high level of engagement with a certain activity, introduces to his work specialty in ideas and originality in problem solving (Sternberg, 2005). Creativity, as well as thinking, is not knowledge but ability. Abilities cannot be learned, but they can be trained, therefore more repetitions allow better results (Huzjak, 2006). For this reason, gifted non-creative people become, over time, experts in their field of work and interest. On the other hand, creative individuals, given their character traits that characterize them (curiosity, selfreliance, persistence, negligence towards the environment, self-confidence, willingness to risk), introduce innovations and develop the areas they are dealing with. To do this, enables them their great work energy, internal motivation, enthusiasm and willingness to deal with the subject of their interest long and intensively (Brđanović, 2015).

\section{Gifted pupils in the Croatian educational system}

In the Republic of Croatia, with the exception of rare situations, school practice systematically stimulates intellectual and neglects creative development (Brđanović, 2015). In this way, although the declarative attitude of encouraging gifted ones is present, it does little to their real identification and potential realization, and hence the gap between the potential and the accomplished giftedness is great.

That is why it is an imperative to provide for gifted children a broad and balanced experience and development of skills, knowledge, concepts and attitudes that will complement their personality. "Gifted child, as well as every other child, needs an indispensable educational program that provides challenges and opportunities for self-expression, reaching out to the perception of their own possibilities and for an independent opinion." (Cvetković-Lay, 2002). The necessity of such a curriculum for gifted children derives from their characteristics that are different in relation to other children and which cannot be expressed or developed without proper challenges and incentives. Through such curriculum they carry out activities that develop logical, creative thinking and creativity, and through experiential learning children's knowledge deepen, skills and abilities develop.

The manner of observing, educating, encouraging and monitoring gifted pupils in the Republic of Croatia is defined by the Ordinance on Primary Education and the Education of Gifted Pupils from 1991. According to it, the giftedness of a child is defined in the definition of "the combination of three basic groups, the attributes: above-average general or specific abilities, motivation and high degree of creativity, and according to the 
abilities the areas of giftedness are: general intellectual ability, creative skills, abilities for individual artistic areas, and psychomotor abilities." (Ordinance on Primary Education and the Education of Gifted Pupils, 34/1991.). This Rulebook defines the general rights of gifted pupils and school responsibilities such as a differentiated program or the possibility for acceleration. Thus, the area of development of giftedness and work with gifted pupils is defined by one rulebook containing 16 articles and has not been changed nor supplemented for over twenty-five years. The ordinance gives only formal guidelines and provisions, but not concrete proposals and instructions for work. According to it, the Institute for Education (now Educational Agency) should have developed professional guides and instruments for determining gifted pupils (assessment scales for teachers, parental questionnaires, sociometric techniques, etc.) but nothing has been done, so everything still depends on the initiative and the commitment of teachers, associates and schools. In the schools of the Republic of Croatia, working with pupils who show intensified interest in some area, and we can not talk about gifted pupils because they are not identified by any measuring instruments, is based on one additional class per week.

Due to often inadequate curriculums and content that is being processed and which causes boredom and disinterest, gifted pupils can be negligent or hinder other pupils from their activities. Due to the lack of systems worries, they are often in conflict with their environment, are considered inappropriate, and are assessed as "impossible", "overwhelmed" or "aggressive." Since gifted children are cognitively more advanced than their peers, their fitting into a peer group can be barred. That is why a gifted child might feel weird or different and begin to hide his talents in order not to emphasize.

Knopper research (1999, according to Mula, Janus, Palomar, 2016) has shown that gifted children have the greatest problems of social adaptation. In some situations, a gifted six-year-old child can behave like a twelve-year-old while solving math tasks, like an eight-year-old while playing football or like five-year-old when he loses his favorite toy. Such breakthroughs in emotional and psychological reactions may make it difficult to make friendships and to finish the process of socialization. In her paper, Sekulić-Majurec (1995) observes a phenomenon of giftedness from the perspective of the influence of family factors on the development of giftedness and points out that children acquire a certain potential through their inheritance, while the extent to which it develops depends on a number of factors from the environment. Some of these factors are the upbringing, including development of a positive image of self, level of education of parents, financial situation, stimulating environment, early recognition, favorable conditions for the development of giftedness and school environment. Gross (2003) has proved in his research, that gifted children are more introverted, they prefer to spend time alone, have a very small number of close friends, and often isolate themselves from others by doing the activity their talent is dominant in. Being introverted does not need to be considered a negative feature. This does not necessarily mean that the child is ineligible, unacceptable or frightened in the society. Often, introverted children use their time to think, observe, and summarize thoughts and feelings (Sheely, 2010).

The research monograph by Callahan, Sowa, May, Menaker Tomchin, Plucker, Cunningham, and Taylor (2004) describes the studies that examine the social and 
emotional development of gifted students. The results of one of the studies which researched demands and pressures of family and school on gifted pupils showed that gifted children mostly come from the families which emphasize individual work and action, thus it is necessary to stress the importance of accepting social norms through different ways of communication and interaction with the environment. Another study investigated the reactions of gifted male and female pupils aged from 10 to 16 years to stress. It has been noted that gifted male and female pupils take responsibility in dealing with stressors and rather take conscious actions to manage them instead of ignoring the issue. The third study examined family experiences in upbringing gifted children, as well as difficulties with their social adjustment. The results showed that gifted children often experience problems in social and emotional adjustment. Cooperation of the family, child and school proved to be crucial in monitoring the children's development and solving the issues.

Contemporary school emphasizes the need for individualization of classes and the application of differentiated programs. The individualized approach in educational work implies adapting objectives, tasks and contents to the pupils' abilities, possibilities, preferences, their existing knowledge and their interests.

Instead, the Croatian educational system adapts the work to the abilities of an average pupil, which means that the same goals and tasks are set for children who are different in their abilities, interests, habits, etc.

Since there are many specifics that gifted children make extremely vulnerable to inadequate educational environment, they are very important to be detected and accessed with individually made programs tailored to their needs, but first of all there is a need for training the teachers and associates to work with such children, without ignoring parents and the wider social community, who often ignores gifted children and their families because of ignorance and misunderstanding.

The system of regular education, educational process and activity, is designed for the needs of an average pupil. Gifted children are included in the regular educational system in Croatia, and for each gifted child there should be an individual plan and program drawn up together by the teachers and expert associates of the school that the child is attending. Crljen and Polić (2006, according to Adžić, 2011) emphasize the importance of integrating gifted preschool and school children into a regular system, but with an individualized approach. They stress that for especially talented pupils there need to be devised and implemented shorter additional programs that would be both didactic and methodically rich and diverse, focused on a higher degree of thinking, conclusion and creativity i.e. the future.

For productive work with gifted children, mostly are needed positive teacher's attitudes. The consequences of negative attitudes are refusal and avoidance of recognition and special, differentiated work with gifted ones. Čudina - Obradović and Posavec (2009) conducted a study on the positivity, negativity and ambivalence of teacher's attitudes on working with gifted pupils. Results show that positive attitudes on giftedness depend on personal experience in working with gifted children, that more positive attitudes have individuals who have had pleasant experiences with gifted ones, and finally more positive 
attitudes have those who are busier with work and more satisfied with work, and teachers with longer working experience.

In order to encourage the giftedness of the pupil, but not to get burden by the demands of him, teacher must have good pedagogical-psychological preparation and apply additional sources of knowledge and contemporary teaching methods. Such kind of professional training for teachers in the Republic of Croatia is neglected and the teachers mostly develop themselves by evaluating the pupils with the help of different types of gift scales that are not standardized and officially defined. There is no officially defined process of identification of gifted schoolboys/schoolgirls.

Research findings Nikčević - Milković, Jerković and Rukavina (2016) on the situation and needs of working with gifted pupils in elementary schools in Republic of Croatia among teachers and professors have shown that teachers in central and northern region of Croatia, compared to southern, statistically significantly more care about gifted and talented pupils. Teachers of all profiles working with gifted and talented pupils are statistically most important working on special programs, methods and forms of work, moreover, take immediate care of the gifted but at least participate in the identification of gifted and talented pupils. All classes of teachers regard the years of service, as well as education on the gifted, statistically perform most special programs, methods and forms of work with the gifted, then take immediate care of them and at least participate in their identification. Care for gifted and talented pupils in the Republic of Croatia is still not at a satisfactory level. In defining the giftedness most important is methodology of gifted pupils recognition and strategy for working with them. Therefore, it is essential to shape a national strategy or to systematize the educational policy for working with gifted pupils.

\section{Work programs with gifted pupils in European school systems}

The authors Reid and Boettger (2015) note that the education of gifted children today differs from one country to another. On the one hand, there are countries with detailed programs for gifted pupils, and on the other hand, there are countries which do not recognize at all the terms giftedness and gifted pupils in their educational systems. However, most countries identify gifted pupils and provide them out-of-school support of different institutions, organizations and associations. They also point out that sometimes there can be heard an opinion in schools that gifted pupils do not require a special attention and a different approach because they can fit very well in an average population of pupils. Certainly, this is a misconception which, if accepted, can hinder the development of gifted pupils' maximum potentials. Gifted pupils require a special attention.

In most of the EU countries, there has been recognized the importance of working with gifted children, so curriculums and programs are regularly conducted for gifted children of preschool and school age. Programs often differ, but have a common starting point, which is to provide the best and most appropriate content from the school system by the individual approach to the child/pupil's needs (Kukanja Gabrijelčič, 2012). Persson (2009) estimates that among the Scandinavian countries in the field of education, Finland 
has a leading role, but in spite of this, it does not stand out sufficiently in the care of gifted pupils. Malta, Norway and Scotland, for example, do not carry out any procedures for identifying gifted pupils. In most European countries, according to Gifted Learners: A Survey of Educational Policy and Provision (2009), the process of identifying gifted pupils is carried out using as many different types of data. Most prevalent are diagnostic instruments that are being combined with other methods, for example the opinion of teachers and parents.

Another important international trend has lately been the formation of national strategies and educational policies for working with gifted ones. Basically, this stems from the understanding of the educational needs of gifted pupils; unlike pupils with special needs who have learning difficulties, gifted pupils point out to their potential and learning abilities, because their further development does not need learning aids but a stimulus for the realization and development of their talents (Juriševič, 2012). Thus, in international research from 2006. to 2009., there is a decrease in the number of countries which classified gifted pupils in a group of pupils with special needs. According to the data of the Specific Educational Measures to Promote All Forms of Giftedness at School in Europe (Eurydice, 2006), ten countries classified gifted pupils in a group of pupils with special needs (Czech Republic, Estonia, France, Greece, Ireland, Slovakia, Slovenia, Scotland, Spain, Portugal), 2009. according to the Gifted Learners: A Survey of Educational Policy and Provision (2009), five countries still had different interpretations of the term "special needs" (Slovenia, Estonia, France, Greece and Ireland), and gifted pupils were still ranked amongst pupils with special needs but for them the law did not foresee any adjustments. That is why, for example, Slovenia, in accordance with the international trends of 2011., adopted the law on gifted pupils as an autonomous group independent from other pupils with special needs

J. Freeman, J. Raffan and Warwick (2010, according to Juriševič, 2012) conclude that different methods of identification are combined in different countries of the world. The most commonly is considered teacher rating $(80 \%)$, followed by pupil's school grades and scores of knowledge exams (62\%), parents and environment (62\%), intellectual ability tests $(54 \%)$, other tests $(51 \%)$, school psychologists rating (48\%), pupil performance during classes $(45 \%)$ and creativity tests $(23 \%)$.

Inclusion becomes more and more present in different countries (Freeman, Raffan and Warwick, 2010), as it provides increased care for the full development of gifted pupils. In most European countries, gifted pupils are educated in the regular classes of elementary schools according to the principle of inclusiveness, while different forms of differentiation are encouraged, which will allow individualized access, deepening and expansion of the curriculum to those content that stimulate the development of specific abilities, talents and creativity but on a way to respect the rights of all pupils, individual differences and in no case encourage the emphasis on greater individual values or elitism (Hymer and Michael, 2002). A partnership is being established between the various participants included in the education and training of gifted pupils. In 23 European countries, pupils are included in regular primary school classes, the "mixed model" (special and regular classes) have Denmark, Germany, Hungary, the Netherlands and 
Switzerland. Estonia, Hungary and Switzerland also have special (state) schools for gifted pupils, and private institutions for gifted pupils are in Austria, Denmark and Estonia. It follows from all of the above that in most of the countries gifted pupils are offered optional, special or additional programs within regular education. Individualization is the basis of work with gifted pupils in 20 European countries, acceleration is present in 19 and there is also the wealth of additional (enriched, extended) programs, counseling and various forms of differentiation. J. Freeman, J. Raffan and Warwick (2010) on the basis of an international study emphasize the increased trend of inclusive education and education of gifted pupils. They also conclude that in most countries the most common education system for gifted pupils are regular classes of elementary school with extended programs and different forms of differentiation.

Table 1. (Juriševič, M. (2012). Nadarjeni učenci v slovenski šoli) List of countries classification and recognition of gifted children (European Agency for Development in Special Needs Education, 2009)

\begin{tabular}{|c|c|c|c|c|c|c|c|c|c|c|c|c|c|c|c|c|c|}
\hline & \multirow[t]{2}{*}{1} & \multirow[t]{2}{*}{2} & \multirow[t]{2}{*}{3} & \multicolumn{9}{|l|}{4} & \multirow[t]{2}{*}{5} & \multicolumn{4}{|l|}{6} \\
\hline & & & & 4.1 & 4.2 & 4.3 & 4.4 & 4.5 & 4.6 & 4.7 & 4.8 & 4.9 & & 6.1 & 6.2 & 6.3 & 6.4 \\
\hline Austria & - & - & + & + & + & + & + & + & + & + & + & - & + & + & + & - & - \\
\hline Belgium* & - & - & - & + & + & + & + & + & + & + & + & + & - & + & + & + & - \\
\hline Ciprus & - & - & - & + & + & - & + & - & - & + & - & - & - & + & - & - & - \\
\hline $\begin{array}{l}\text { Czech } \\
\text { Republic }\end{array}$ & + & - & + & + & + & + & + & + & + & + & + & + & I & + & + & - & - \\
\hline Denmark & - & - & + & - & + & - & + & + & + & - & - & - & - & + & + & - & - \\
\hline Estonia & - & + & - & + & + & + & + & + & + & + & + & - & + & + & - & + & - \\
\hline Finland & - & - & - & + & + & - & - & + & - & - & - & - & - & + & - & - & + \\
\hline France & + & + & + & - & - & - & + & - & - & + & + & - & - & + & + & - & - \\
\hline Germany & - & - & - & + & + & + & + & + & + & + & + & - & l & + & + & - & - \\
\hline Greece & + & + & + & + & + & + & + & + & - & - & - & - & + & + & + & - & - \\
\hline Hungary & - & - & + & + & - & + & - & - & + & - & - & - & - & + & + & - & + \\
\hline Island & - & - & - & + & + & + & - & - & - & - & - & + & - & + & - & - & - \\
\hline Ireland & - & + & - & + & + & + & + & + & + & + & + & + & + & - & + & - & - \\
\hline Lithuania & + & - & + & + & + & + & + & - & - & - & - & + & + & - & - & + & - \\
\hline Malta & - & - & - & - & - & - & - & - & - & - & - & - & - & - & - & - & - \\
\hline Netherlands & - & - & + & + & + & + & + & + & + & + & + & + & 1 & + & + & - & - \\
\hline Norway & - & - & + & - & - & - & - & - & - & - & - & - & - & + & + & - & - \\
\hline Portugal & - & - & + & + & - & + & - & + & - & - & - & - & + & + & - & - & - \\
\hline Slovenia & + & + & + & + & + & + & + & + & + & + & - & + & + & - & - & + & - \\
\hline
\end{tabular}




\begin{tabular}{|l|l|l|l|l|l|l|l|l|l|l|l|l|l|l|l|l|l|}
\hline Spain & + & - & + & + & + & + & + & + & + & + & + & - & + & + & + & - & - \\
\hline Sweden & - & - & - & - & - & - & - & - & - & - & - & - & - & - & - & - & - \\
\hline Switzerland & - & - & + & + & + & + & + & + & + & + & + & - & - & + & + & - & - \\
\hline Scotland & - & - & + & + & + & + & - & - & - & - & - & - & + & + & + & + & + \\
\hline Wales & + & - & + & + & + & + & - & + & + & - & - & - & + & + & + & + & - \\
\hline
\end{tabular}

${ }^{\star}$ French speaking area

+ Existing, - Not existing, /Partial existence

Remark:

1 = special definition of gifted pupils within school legislation; $2=$ gifted pupils are included in a group of pupils with special needs; 3 = needs of gifted pupils are included in the school legislation; $4=$ special procedures for identifying and evaluating giftedness: $4.1=$ teachers, $4.2=$ parents, $4.3=$ pupil's achievements, $4.4=$ intellectual ability testing, $4.5=$ pupil's interview, $4.6=$ diagnostic evaluation procedures, $4.7=$ test of potential abilities, $4.8=$ ability test , $4.9=$ pupil portfolio; $5=$ special training for teacher working with gifted pupils; $6=$ gifted pupil advocates: $6.1=$ parents, $6.2=$ organizations for gifted pupils, $6.3=$ teacher organizations, $6.4=$ gifted pupils themselves.

\section{An example of working with gifted pupils in the Republic of Slovenia}

Successful model of working with gifted pupils has been part of the Slovenian curriculum for fifteen years. Unlike Croatia, where teachers have no obligation, education, guidance to help them identify and work with gifted pupils, moreover, everything depends on school and teacher's sensitivity, Slovenia has been implementing its successful model since 2000. Slovenia has developed several concepts that reveal gifted pupils, on the basis of which a curriculum is being developed. In the Republic of Slovenia, the right and the position of gifted pupils are legally defined through several documents: The White Book of Education and Training in the Republic of Slovenia (1995); The White Book of Education and Training in the Republic of Slovenia (2011); Elementary School Act (1996); Elementary School Act (2006); The concept of discovery and work with gifted pupils in a nine year elementary school in Slovenia (1999); Operationalization of the concept of discovery and work with gifted pupils in nine year elementary school in Slovenia (2000); Operationalization of the concept of discovery and work with gifted pupils in nine year elementary school in Slovenia (2008). The aforementioned documents emphasize the principle of equal opportunities and non-discrimination, the principle of maintaining balance between different aspects of the child's physical and intellectual development, the principle of choice and higher quality of education. It is also said that the state needs to establish mechanisms for introducing pluralism and right to choice at all levels; in school activities through the proper application of different methods and in as much flexibility in spatial and hour organization as possible. The schools are committed to organize additional classes, creating and applying differentiated programs, enabling a 
faster completion of elementary education in cooperation with the school's professional service and parents and keeping records of work with gifted pupils (Kukanja Gabrijelčić, 2012).

The fundamental meaning of working with gifted children is an individual approach to a child, as well as adjusting education in accordance with his talent and interest. In the process of discovery of gifted pupils in the Republic of Slovenia, participate professors, school counselors, parents, and sometimes external experts.

The discovery model includes: recording - is assessed on the basis of school success, extraordinary achievements in the art, music, technical, sports and other areas, professors opinions, competitions, hobbies, opinions of the school advisor; identification - test of creativity, intelligence test; notifying parents and their opinions. Besides pupils, Slovenia saw how important it is to educate teachers, school psychologists and pedagogues so that their work with gifted pupils could be as high as possible (Žagar, 2006). All steps are planned, records and identification procedures are complex, each implies more data to gain the most credible results of pupil's giftedness. In the process of recording (Juriševič, 2012), at least one of the following characteristics is taken into account: high school success, unique achievement, high teacher assessment of pupil's above-average skills, best successes at regional and state competitions, excellence in the field of interest (hobby) and positive opinion, i.e. the proposal of the school. The recorded pupils are then included in the identification process that includes three types of measurements by Boben (2006, according to Jurišević, 2012): a teacher's assessment of the pupil's talents on the basis of OLNAD07 instrument, ability test (WISC) and creativity test (TTCT Torrance Tests of Creative Thinking). Pupils, who at least at one of these measurements achieve an above-average score (upper 10\%), are identified as gifted pupils. The third step in the identification process involves the parent's opinion on the child's giftedness and their reporting on the test results. The final grade of pupil's giftedness is made by a teacher's council in collaboration with the school's professional staff and coordinators for working with gifted pupils at school.

\section{Professional training of teachers for work of gifted pupils in Republic of Slovenia}

One of the most important components of working with gifted pupils are educated and motivated teachers. In the Republic of Slovenia a network of partnerships between schools and faculties is developed, they try to train pupils and teachers through various types of collaboration and projects. Practical training of teachers to work with gifted pupils begins during their studies but is more intense during their internship and work experience in school (Razdevšek - Pučko, 2007). The most common examples of partnerships are presented at the beginning of teacher education when teacher mentors provide pupils with their experience of working with gifted pupils. Direct contact with someone who has experienced the mode of work, meets the requirements that this way of thinking implies, allows pupils an experiential learning, adoption of ideas and exchange of mentor thinking. The role of the mentor is in the articulation of thinking and in the 
formation of teaching methods.

Besides partner relationships in the field of teacher training, most commonly are present classic forms of formal projects involving various state institutions, and are based on action research. The Ministry of Education and Sports and the School of Education of the Republic of Slovenia also organize professional trainings for teachers in the form of seminars and conferences. All forms of professional training of teachers are based on the fact that all children deserve the highest quality of education that can be provided by highly educated teachers. The highest quality in the area of education can be achieved if the teachers adhere to their fundamental noble responsibilities of teaching gifted and talented pupils, knowing their abilities, characteristics and different needs. Gifted pupils are a kind of challenge and temptation in the work of teachers with their special educational and social - emotional needs (Kukanja Gabrijelčič, 2014). For successful work with gifted pupils, teachers need to know how to evaluate the nature of their abilities, understand the cognitive, social and emotional features, needs and potential difficulties they face, they need to have knowledge, skills, ideas and access to content and information that modern technology provides, also, they need to have the ability to develop differential programs for work with the unique intellectual and emotional needs and interests of pupils, the ability to create a safe and stimulating environment in which gifted pupils can easily express their unique abilities and talents (Kukanja Gabrijelčič, 2012).

From all of the above, it can be concluded that the aim of the teacher's work in teaching gifted pupils is to help the pupil, his constant aspiration to the progress of the pupils in development and the optimum utilization of their abilities and skills in order to change their actions and their wider social environment by their actions.

\section{CONCLUSION}

If we compare the orientation of most European Union countries on the importance of working with gifted pupils through the development of national programs and education policies, we can easily conclude that the Republic of Croatia work on the issue is not sufficient. There are no legal regulations regarding records, identification and working methods with gifted pupils. In the absence of systematic identification in Croatian schools, teachers and professors are still the most common estimators of talent, they play a key role in identifying and working with gifted pupils, although there is no systematic education and training for them. Training is largely left to the individual's needs, desires and aspirations. According to Vojnović (2005), teachers who are better educated and have more experience in working with gifted are relatively more successful evaluators of gifted pupils. Teachers need to be provided support and education to enhance their work with pupils in different types of classes, especially in regular classes through individualized access and differentiation programs and in additional tuition through election, extracurricular classes and programs and competitions. Teachers also demonstrate the need for modernization of contemporary forms and methods of work. Likewise, the need for more systematic professional training on working with gifted pupils 
is expressed by pedagogues, psychologists, speech therapists, i.e. all the professional staff who everyday meet with gifted pupils. This relationship towards gifted pupils and the lack of systematic care is a mirror to the ineffectiveness of the Croatian democracy, since securing the conditions for full development and education to everyone in accordance with their individual capabilities is something that requires societies with highly developed democracies and international institutions fighting for it. These children are deprived of their fundamental rights, and care is most often left to their parents only, i.e. their educational and material opportunities to compensate for systematic omissions of society and the state (Nikčević - Milković, Jerković, Rukavina, 2016). In contrast to Croatia, in most modern democratic states, awareness of the importance of working with gifted pupils and the development of their abilities and talents has evolved, because the future, growth and development of modern society is based on them. Observing experience and practice the neighboring Republic of Slovenia in working with gifted pupils, Croatian educational system could improve much. The right and position of gifted pupils must be clearly defined as soon as possible. The current way of seeing, educating, encouraging and monitoring gifted pupils in the Republic of Croatia is defined by a single and outdated document, the Ordinance on Primary Education and the Education of Gifted Pupils (34/1991). Taking into account all aspects of the development of modern society, it is understandable that it is impossible for teachers to follow the guidelines laid down by the twenty-five years old rulebook, in their daily work. It is necessary to improve communication and cooperation at all levels of the education system and among all participants in the educational process. The competent Ministry should provide schools with working conditions that will enable individual teachers to work with gifted pupils, facilitate and clearly define ways of identifying gifted pupils, stimulate continuous professional training for teachers and associates in the field, as well as communication and collaboration between higher education institutions that will educate future educators. Gifted pupils need to be offered with as many different programs through extracurricular activities which will develop their abilities, and in the whole process it is immensely important to involve parents as equal partners, as the ultimate goal of the child's wellbeing is shared by everyone. Therefore, in the Croatian educational system the competent institutions should raise awareness of the importance of individual growth and development of gifted pupils, as it is immensely important for the development of the whole society and the vision of a brighter future.

\section{REFERENCES}

1. Adžić, D., (2011). Darovitost i rad s darovitim učenicima, Kako teoriju prenijeti u praksu. Život i škola, 57 (25):171 - 184.

2. Brđanović, D., (2015). Glazbena darovitost i obrazovni sustav. Školski vjesnik, 64 (4): $661-678$.

3. Callahan, C.M., Sowa, S.J., May, K.M., Menaker Tomchin, E., Plucker, J.A., Cunningham, C.M.,Taylor, W., (2004). The Social and Emotional Development of 
Gifted Students, Virginia, University of Virginia, Preuzeto 4.lipnja 2017. s http://files. eric.ed.gov/fulltext/ED505462.pdf

4. Cvetković Lay, J. (2010). Darovito je, što ću sa sobom? Zagreb: Alinea.

5. Cvetković Lay, J. (2002). Ja hoću i mogu više. Zagreb: Alinea.

6. Cvetković Lay, J., Sekulić-Majurec, A., (2008). Darovito je, što ću s njim? Zagreb: Alinea.

7. Čudina - Obradović, M., Posavec, T. (2009). Korelati pozitivnih, negativnih i ambivalentnih gledišta učitelja o darovitosti. Napredak, 150 (3-4): 425 - 450. Preuzeto s http://hrcak.srce.hr/82827

8. Elementary School Act, Uradni list RS, št. $12 / 96 \mathrm{z}$ dne 29. 2. 1996., Preuzeto 7. lipnja 2017. s http://pisrs.si/Pis.web/pregledPredpisa?id=ZAKO448

9. Elementary School Act, Uradni list RS, št. 60/06 z dne 9. 6. 2006., Preuzeto 7.lipnja 2017. s http://pisrs.si/Pis.web/pregledPredpisa?id=ZAKO4644

10. Eurydice, (2006), Specific Educational Measures to Promote All Forms of Giftedness at School in Europe, Preuzeto 4.lipnja 2017. s http://www.indire.it/lucabas/lkmw_ file/eurydice/Specific_measures_giftedness_EN.pdf

11. Freeman, J., Raffan, J., Warwick, I. (2010). Worldwide provision to develop gifts and talents: An international survey. Research report.

12. Gifted Learners: A Survey of Educational Policy and Provision, (2009), European Agency for Development, Preuzeto 9.lipnja 2017. s https://www.pef.uni-lj.si/ fileadmin/Datoteke/CRSN/branje/Gifted_Learners_A_Survey_of_Educational_ Policy_and_Provision_2009_.pdf in Special Needs Education

13. Grgin, T. (1996.). Edukacijska psihologija. Jastrebarsko: Naklada Slap.

14. Gross, M. (2003.). All gifts are equal but some gifts are more equal than others. Understanding our Gifted, 15: 8-12.

15. Hymer, B., Michel, D. (2002). Gifted and talented learners. Creating a policy for inclusion. London: David Fulton.

16. Huzjak, M. (2006). Darovitost, talent i kreativnost u odgojnom procesu. Odgojne znanosti, 11 (1): 232-238.

17. JLZ (1955-1964). Enciklopedija Leksikografskog zavoda, sv. 7. Zagreb: JLZ.

18. Juriševič, M. (2012). Nadarjeni učenci v slovenski šoli. Ljubljana: Pedagoška fakulteta Univerze v Ljubljani, Preuzeto 4.lipnja 2017. s https://www.pef.uni-lj.si/fileadmin/ Datoteke/CRSN/branje/Nadarjeni_ucenci_v_slovenski_\%C5\%A1oli_2012_.pdf

19. Koren, I. (1989). Kako prepoznati i identificirati nadarenog učenika. Zagreb: Školske novine https://www.google. 


\section{DAROVITI UČENICI U HRVATSKOM I SLOVENSKOM OBRAZOVNOM SUSTAVU}

\section{SAŽETAK}

Razvitak i napredak svakog društva u velikoj mjeri ovise o tome kakav je odnos prema njegovim najsposobnijim članovima te o primjerenoj brizi za razvoj njihovih potencijala. Daroviti učenici svakako su jedna od najbitnijih sastavnica društva o kojoj bi odgojno - obrazovni sustav trebao voditi posebnu brigu. Za razliku od Republike Hrvatske, gdje je razvoj ove skupine učenika u odgojno -obrazovnom sustavu zapostavljen, u većini europskih zemalja sve se više shvaća važnost nastavnih programa koji se temelje na individualiziranom pristupu nadarenim učenicima te oblikovanju nacionalnih strategija i odgojno - obrazovnih politika za rad s darovitima. Republika Slovenija svoj uspješan model rada $s$ darovitim učenicima provodi već petnaestak godina. Razvijeno je nekoliko koncepata kojima se otkrivaju daroviti učenici na temelju kojih se izrađuje plan i program nastave, a pravo i položaj darovitih učenika su zakonski definirani kroz mnoštvo dokumenata. Isto tako, velika se pažnja posvećuje stručnom osposobljavanju i usavršavanju učitelja za rad s darovitim učenicima. Gledajući pozitivne primjere susjednih zemalja u radu s darovitim učenicima neophodno je važno raditi na poboljšanju odnosa prema darovitim učenicima i sustavne skrbi u školama Republike Hrvatske.

Ključne riječi: darovitost; diferencijacija; identifikacija; odgojno - obrazovni sustav 


\title{
STUDENTI DOTATI NEL SISTEMA DI EDUCAZIONE CROATA E SLOVENA
}

\begin{abstract}
ASTRATTO
Lo sviluppo e il progresso di ogni società dipendono in larga misura dal rapporto con i suoi membri più capaci e dalla cura necessaria per lo sviluppo del loro potenziale. Gli studenti dotati sono certamente uno dei componenti più importanti della società a cui il sistema educativo deve prestare particolare attenzione. A differenza di Reppublica Croata, in cui lo sviluppo di questo gruppo di studenti nel sistema educativo è trascurato, nella maggior parte dei paesi europei si capisce sempre di più l'importanza di programmi che si basano su un approccio personalizzato per gli studenti dotati e la creazione di strategie nazionali e di istruzione - politiche dell'istruzione per affrontare dotati. La Repubblica Slovenia sta attuando il suo modello di lavoro di successo con studenti dotati per quindici anni. Sono sviluppati diversi concetti che rivelano studenti dotati, sulla base di quali è costituito curriculum, il diritto e il luogo degli studenti dotati sono legalmente definiti da una moltitudine di documenti. Allo stesso modo, grande attenzione viene prestata alla formazione professionale e all'aggiornamento degli insegnanti per lavorare con studenti dotati. Guardando gli esempi positivi di paesi limitrofi a lavorare con gli studenti di talento è indispensabile un lavoro importante per migliorare le relazioni verso gli studenti dotati e la cura sistematica nelle scuole croate.
\end{abstract}

Parole chiave: talento; differenziazione; identificazione; sistema 